\title{
Hydraulic fracturing: Assessing self-reported familiarity and the contributions of selected sources to self-reported knowledge
}

\section{Authors: Gene L. Theodori and Colter Ellis}

NOTICE: this is the author's version of a work that was accepted for publication in The Extractive Industries and Society. Changes resulting from the publishing process, such as peer review, editing, corrections, structural formatting, and other quality control mechanisms may not be reflected in this document. Changes may have been made to this work since it was submitted for publication. A definitive version was subsequently published in The Extractive Industries and Society, 4, no. 1, (January 2017)] DOI\# 10.1016/j.exis.2016.11.003

Theodori, Gene L, and Colter Ellis. "Hydraulic fracturing: Assessing self-reported familiarity and the contributions of selected sources to self-reported knowledge." The Extractive Industries and Society 4, no. 1 (January 2017): 95-101.

Made available through Montana State University's ScholarWorks scholarworks.montana.edu 


\title{
Hydraulic fracturing: Assessing self-reported familiarity and the contributions of selected sources to self-reported knowledge
}

\author{
Gene L. Theodori ${ }^{\mathrm{a}}$, Colter Ellis ${ }^{\mathrm{b}}$ \\ a Department of Sociology, Sam Houston State University, Box 2446, Huntsville, TX 77341, USA \\ b Department of Sociology, Montana State University, Box 172380, Bozeman, MT 59717-2380
}

\begin{abstract}
Data collected from a random sample of individuals in two counties in the Eagle Ford Shale region of South Texas to examine (a) respondents' self-reported familiarity with the process of hydraulic fracturing and (b) the associations between the contributions of information sources to self-reported knowledge about hydraulic fracturing and self-reported levels of familiarity with the process of hydraulic fracturing. The results of this study revealed that survey respondents in the Eagle Ford Shale region of Texas are more familiar with the process of hydraulic fracturing than has been reported in other studies. Moreover, the findings indicated that self-reported levels of familiarity with the process of hydraulic fracturing were positively associated with certain sources of information. Among those sources that reached statistical significance, the strongest contributor to respondents' self-reported familiarity with hydraulic fracturing was information from the oil/natural gas industry.
\end{abstract}

\section{Introduction}

The industrial process of hydraulic fracturing-frequently referred to as fracking in the media, public discourse, peerreviewed articles, and popular press writings-has been, and remains, a highly controversial topic in domestic and international discussions regarding shale energy development. The controversies surrounding hydraulic fracturing have sparked the conduct of timely and salient research studies in the United States and abroad by social, behavioral, and environmental scientists interested in investigating the pros and cons of shale oil and gas development. A rapidly growing body of domestic and international scientific literature has contributed to increased understandings of the multitude of objective and perceived issues associated with shale development and hydraulic fracturing, including economic issues (Considine et al., 2010; Kinnaman, 2011; Kelsey et al., 2011; Mason et al., 2015), public health issues (Colborn et al., 2011; Finkel and Law, 2011; Osborn et al., 2011; Schmidt, 2011; Shonkoff et al., 2014), environmental issues (Macey et al., 2014; Qingmin, 2015; Qingmin and Ashby, 2014; Olmstead et al., 2013; Jeff, 2012), and sociological issues (Anderson and Theodori, 2009; Crowe et al., 2015a,b; Davis and Fisk, 2014; Ellis et al., 2016; Hudgins, 2013;
Kreuze et al., 2016; Ladd, 2013; Perry, 2012; Theodori, 2009, 2013; Weigle, 2011; Willits et al., 2013; Willow and Keefer, 2015).

Largely absent from the social scientific research conducted thus far are empirical studies directed toward assessing stakeholders' knowledge and understanding of shale development and the process of hydraulic fracturing itself. Of late, a small number of researchers have begun to measure perceived familiarity-also referred to "self-reported knowledge" or "perceived knowledge"(Ladwig et al., 2012:762)-with shale development in general (Stedman et al., 2012, 2016; Willits et al., 2013) and hydraulic fracturing in particular (Boudet et al., 2014; Theodori et al., 2014; Willits et al., 2016a,b). Less empirical work has examined the sources of information that individuals use to become educated about shale development and hydraulic fracturing (Theodori et al., 2014). Despite these studies, perceived familiarity with shale development and hydraulic fracturing and the sources that contribute to self-reported knowledge of these topics remain underinvestigated (cf. Stedman et al., 2016). Paraphrasing recent assertions by Stedman et al. (2016), additional research is warranted to more fully comprehend the sources and processes by which members of the general public do, in fact, become informed. Robust research on such issues will result in an improved understanding of individuals' attitudes, behaviors, and behavioral intentions with respect to shale development and hydraulic fracturing. Moreover, the findings from such work has 
Table 1

Contributions made by fifteen sources of information to self-reported knowledge about hydraulic fracturing.

\begin{tabular}{|c|c|c|c|}
\hline \multirow[t]{2}{*}{ Sources of Information } & \multirow[t]{2}{*}{$\mathrm{n}$} & \multicolumn{2}{|c|}{ Contributions to Self-Reported Knowledge of Hydraulic Fracturing } \\
\hline & & $\begin{array}{l}\text { None/Very Little } \\
\text { Percentage }\end{array}$ & Some/A Great Deal \\
\hline Newspapers & 107 & 35 & 65 \\
\hline Oil/natural gas industry & 106 & 36 & 64 \\
\hline Internet websites & 104 & 39 & 61 \\
\hline Neighbors & 104 & 42 & 58 \\
\hline Friends in community & 106 & 43 & 57 \\
\hline Landowner groups/coalitions & 106 & 53 & 47 \\
\hline Social media & 106 & 60 & 40 \\
\hline Conservation/environmental groups & 106 & 61 & 39 \\
\hline Regulatory agencies & 104 & 64 & 36 \\
\hline Texas A\&M AgriLife Extension & 105 & 72 & 28 \\
\hline University professors & 106 & 74 & 26 \\
\hline Elected county officials & 104 & 74 & 26 \\
\hline Gasland and/or Gasland 2 (the films by Josh Fox) & 104 & 77 & 23 \\
\hline Elected city officials & 105 & 80 & 20 \\
\hline Religious leaders & 107 & 85 & 15 \\
\hline
\end{tabular}

the potential to affect energy policy, which has, and continues to be, influenced by public opinion.

The purpose of this paper is to add to the social scientific literature on shale development and hydraulic fracturing. Here, building upon previous research in the Marcellus Shale (Theodori et al., 2014; Willits et al., 2016a,b), we use data collected from a random sample of individuals in two counties in the Eagle Ford Shale region of South Texas to examine (a) respondents' selfreported familiarity with the process of hydraulic fracturing and (b) the associations between the contributions of information sources to self-reported knowledge about hydraulic fracturing and self-reported levels of familiarity with the process of hydraulic fracturing. Before describing the data, measurement, and findings, previous studies investigating individuals' familiarity with hydraulic fracturing are summarized.

\section{Previous studies}

Boudet et al. (2014) used data collected from a sample of United States citizens to explore several issues associated with hydraulic fracturing. These issues included: 'top of mind' associations, familiarity with hydraulic fracturing, levels of support/opposition for hydraulic fracturing, and possible factors that may be predictors of support for hydraulic fracturing. In their study, Boudet et al. (2014) measured familiarity with hydraulic fracturing with a single question. The question asked: How much have you ever heard or read about fracking? Response categories (as reported in Table 1 in their manuscript, p. 62) included: (1) not at all, (2) a little, (3) some, and (4) a lot. In the Findings section, Boudet et al. (2014:63) reported that "13\% did not know how much they had heard; 39\% had heard nothing at all; 16\% heard 'a little'; $22 \%$ heard 'some'; and 9\% heard 'a lot."'1 The results of their hierarchical multiple regression analysis relating demographics, geographic location, worldviews, political ideology, media use frequency, familiarity with fracking, and 'top of mind' associations to support/opposition for hydraulic fracturing revealed that individuals who were more familiar with hydraulic fracturing were more likely than their counterparts to oppose hydraulic fracturing. Furthermore, their results illustrated that women, individuals holding egalitarian worldviews, individuals who read newspapers more than once a week, and individuals who associate hydraulic fracturing with environmental impacts were more likely

\footnotetext{
${ }^{1}$ A discrepancy exists between the response categories listed in Boudet et al.'s (2014) Table 1 and their Findings section.
}

than their counterparts to oppose fracking. Concomitantly, they found that older individuals, those with a bachelor's degree or higher, those who are politically conservative, those who watch TV news more than once a week, and those who associate hydraulic fracturing with positive economic or energy supply outcomes were more likely than their counterparts to support the process.

Theodori et al. (2014) used survey data gathered in Pennsylvania's Marcellus Shale region to investigate individuals' levels of familiarity with: (1) the process of hydraulic fracturing; (2) the management and disposal of frac flowback wastewater; and (3) frac flowback wastewater treatment technology. In doing so, they examined the contribution made to self-reported knowledge of hydraulic fracturing by eight different sources and the amount of trust in each of the same sources to deliver unbiased, factual knowledge about the topic. Then, building upon previous research on the public's perception of produced water (Theodori et al., 2009, 2011), Theodori et al. (2014) assessed individuals' level of agreement that treated wastewater from hydraulic fracturing operations could safely be used for eight selected purposes. Theodori et al. (2014) also evaluated the associations between level of familiarity with frac flowback wastewater treatment technology and the proposed potential uses of treated wastewater. Differences in the information reported by survey respondents living in high well-density counties ( 20 or more wells per 100 square miles) and their counterparts living in low well-density counties (fewer than 20 wells per 100 square miles) were examined.

In the Theodori et al. (2014) study, familiarity with the process of hydraulic fracturing was assessed using a single survey item that ranged from 1 (extremely unfamiliar) to 7 (extremely familiar). Findings revealed the overall mean level of familiarity with the process of hydraulic fracturing was $3.73(\mathrm{SD}=1.91)$. Their descriptive results indicated a more or less symmetrical distribution - $40 \%$ of respondents indicated having some level of familiarity with the process of hydraulic fracturing (scores 5 through 7 on the 7-point familiarity scale); $43 \%$ of respondents reported being unfamiliar with the process (scores 1 through 3 on the7-point familiarity scale). Although they did not state a formal hypothesis, Theodori et al. (2014) assumed there would be a difference in the level of familiarity between residents in areas with low and high levels of natural gas drilling activity. Such was the case. As reflected by the results of an analysis of covariance, individuals living in the high well-density counties were significantly more familiar with the process than their counterparts living in low well-density counties, net of control factors (high well-density counties $\mathrm{M}=3.90, \mathrm{SD}=1.89$; low well-density counties $\mathrm{M}=3.55, \mathrm{SD}=1.92(\mathrm{p}<0.05))$. 
With respect to the findings regarding sources of information about the process of hydraulic fracturing, Theodori et al. (2014) noted that respondents reported newspapers, the natural gas industry, conservation/environmental groups, and landowner groups/coalitions contributed more to their knowledge about hydraulic fracturing than did regulatory agencies, Cooperative Extension, university professors, or the film Gasland. Moreover, the overall pattern of responses differed only slightly when it came to whether or not individuals trusted those same sources of information. There, conservation/environmental groups, newspapers, and landowner groups/coalitions retained their designation as being in the top four sources of information, but the natural gas industry was replaced by university professors.

Theodori et al. (2014) also uncovered statistically significant differences between the respondents from low well-density counties and those from high well-density counties with respect to the contributions to self-reported knowledge made by two sources of information and trust in the same two sources. Residents living in the high well-density counties were more likely than those individuals living in the low well-density counties to report they gained some degree of knowledge about hydraulic fracturing from the natural gas industry and regulatory agencies, and that they were more likely than individuals in the low-well density areas to trust these two sources of information to provide unbiased, factual knowledge on the hydraulic fracturing process.

Drawing upon the data gathered in Pennsylvania's Marcellus Shale region (Theodori et al., 2014), Willits et al. (2016a,b) further assessed issues associated with individuals' levels of familiarity with hydraulic fracturing. Willits et al. (2016a) addressed the following two research questions: (1) To what extent do residents report they are familiar with hydraulic fracturing and how does reported familiarity differ depending upon the individuals' sociodemographic characteristics, primary sources of information, density of well development in their counties, and the mode of data collection? and (2) How does perceived familiarity with hydraulic fracturing relate to residents' support or opposition to development of the natural gas industry in their area? Familiarity with hydraulic fracturing was measured with a single Familiarity Index. The familiarity index was calculated by averaging the values for individual's responses on three hydraulic fracturing-related items. These included: (1) Natural gas development in the Marcellus Shale relies heavily on the practice of hydraulic fracturing. On a scale from 1 to 7, where 1 is 'Extremely Unfamiliar' and 7 is 'Extremely Familiar,' how would you assess your familiarity with the process of hydraulic fracturing?, (2) The term 'frac flowback water' refers to water that returns to the surface after a gas well is hydraulically fractured. On a scale of 1 to 7, where 1 is 'Extremely Unfamiliar' and 7 is 'Extremely Familiar,' how would you assess your familiarity with the management and disposal of frac flowback water in the Marcellus Shale?, and (3) Technologies that remove contaminants from frac flowback wastewaters in natural gas field operations currently exist and continue to be refined. On a scale of $1-7$, where 1 is 'Extremely Unfamiliar' and 7 is 'Extremely Familiar,' how would you assess your familiarity with frac flowback wastewater treatment technology?

Based upon their data, Willits et al., (2016a) concluded that the majority of respondents had little or no understanding of hydraulic fracturing $(M=3.2 ; \quad S D=1.7)$. The results of their stepwise regression model revealed that information from the natural gas industry was, by far, the strongest contributor to individuals' familiarity with hydraulic fracturing. Other statistically significant contributors to self-reported knowledge of hydraulic fracturing included information from conservation/environmental groups, gender, and education. With respect to the latter two variables, the data indicated that men and those respondents with higher education were more familiar with hydraulic fracturing than women and those with less education. Moreover, Willits et al., (2016a) analysis illustrated that familiarity with hydraulic fracturing was related to whether respondents stated an opinion concerning their opposition to or support of drilling, but it was not related to what the opinion was. In essence, they found that the higher the perceived familiarity with hydraulic fracturing, the less likely individuals were to indicate they 'neither opposed nor supported' natural gas extraction and the more likely they were to state an opinion. However, among those who stated an opinion, the degree of perceived familiarity with fracturing was not significantly related to whether they opposed or supported drilling.

Lastly, Willits et al. (2016b) used their aforementioned familiarity index in an examination of possible correlates of perceived safe uses of hydraulic fracturing wastewater and individuals' trust in selected sources of information about hydraulic fracturing. Their multivariate logistic regression findings revealed that the familiarity index was positively associated with the perceived safe reuse of treated wastewater by gas and oil industry operators and negatively associated with municipal uses (e.g., watering of golf courses and city parks, etc.). Moreover, multiple correlation/regression analyses indicated that the familiarity index was positively related to trust in the natural gas industry and environmental groups.

\section{Data collection}

Following a modified tailored design method (Dillman et al., 2014), the data for this study were gathered using mail survey techniques. First, in February 2015, an informational letter was mailed to a random sample of 525 residents and absentee landowners in La Salle County, Texas, and 525 residents/absentee landowners in Karnes County, Texas. This letter informed sampled individuals that their household was randomly selected for participation in an upcoming study about public perceptions of oil and natural gas development in the Eagle Ford Shale region of Texas. Three sampled individuals from La Salle County and six sampled individuals from Karnes County contacted the researchers and requested not to participate in the study. These nine sampled individuals were not replaced. Hence, the final sample size was reduced to 1041 .

In March 2015, a survey questionnaire was mailed to the sampled individuals. To obtain a representative sample of individuals within residences, a response from the adult who most recently had his/her birthday was requested in the cover letter. The survey questionnaire, organized as a self-completion booklet, contained 39 questions and required approximately $50 \mathrm{~min}$ to complete. After the initial survey mailing and two follow-up mailings during April and May of 2015, a total of 115 questionnaires were returned ( 44 from La Salle County; 71 from Karnes County). ${ }^{2}$

\section{Measurement}

\subsection{Self-reported familiarity with the process of hydraulic fracturing}

Familiarity with the process of hydraulic fracturing was assessed with a single survey item that ranged from 1 (extremely unfamiliar) to 7 (extremely familiar).

\footnotetext{
${ }^{2}$ For detailed information on the characteristics of the sampled respondents from Karnes County and La Salle County, see Theodori and Uzunian (2015a, 2015b).
} 
Table 2

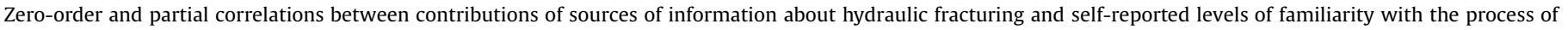
hydraulic fracturing ${ }^{\mathrm{a}}$.

\begin{tabular}{|c|c|c|c|}
\hline \multirow[t]{2}{*}{ Sources of Information ${ }^{\mathrm{b}}$} & \multirow[t]{2}{*}{$\mathrm{n}$} & \multicolumn{2}{|c|}{ Self-Reported Familiarity with Hydraulic Fracturing } \\
\hline & & Zero-order & Partial correlation \\
\hline Newspapers & 90 & 0.12 & 0.14 \\
\hline Internet websites & 87 & $0.26^{*}$ & $0.23^{*}$ \\
\hline Gasland and/or Gasland 2 (the films by Josh Fox) & 88 & 0.06 & 0.10 \\
\hline Texas A\&M AgriLife Extension & 87 & 0.11 & 0.09 \\
\hline Oil/natural gas industry & 91 & $0.41^{* * *}$ & $0.41^{* * *}$ \\
\hline Regulatory agencies & 87 & $0.33^{* *}$ & $0.35^{* * *}$ \\
\hline Conservation/environmental groups & 89 & $0.22^{*}$ & $0.31^{* *}$ \\
\hline Social media & 89 & -0.10 & -0.10 \\
\hline University professors & 88 & 0.13 & 0.16 \\
\hline Landowner groups/coalitions & 89 & 0.09 & 0.02 \\
\hline Neighbors & 88 & 0.14 & 0.12 \\
\hline Friends in community & 91 & 0.16 & 0.05 \\
\hline Elected county officials & 89 & -0.07 & -0.12 \\
\hline Elected city officials & 90 & -0.04 & -0.05 \\
\hline Religious leaders & 91 & -0.10 & -0.14 \\
\hline
\end{tabular}

a Partial correlations were computed controlling for mineral rights ownership and personal/familial ties to the oil and natural gas industry.

b Sources of information are listed as they appeared in the questionnaire.

* Significant at the 0.05 level.

** Significant at the 0.01 level.

*** Significant at the 0.001 level.

\subsection{Contributions of selected information sources to self-reported knowledge about the process of hydraulic fracturing}

Building upon previous work (Theodori et al., 2014), respondents were asked to indicate the degree to which each of 15 sources contributed to what they knew about the process of hydraulic fracturing. The 15 sources included: (1) newspapers; (2) internet websites; (3) Gasland or Gasland 2 (the films by Josh Fox); (4) Texas A\&M AgriLife Extension; (5) oil/natural gas industry; (6) regulatory agencies; (7) conservation/environmental groups; (8) social media; (9) university professors; (10) landowner groups/coalitions; (11) neighbors; (12) friends in community; (13) elected county officials; (14) elected city officials; and (15) religious leaders. Responses were coded as $0=$ none/very little and $1=$ some/ a great deal.

\section{Analyses}

\subsection{Descriptive analyses}

5.1.1. Self-reported familiarity with the process of hydraulic fracturing In total, 7.7 percent of respondents reported being extremely unfamiliar with the process of hydraulic fracturing, and an additional 16.4 percent rated their familiarity at 2 or 3 on the seven-point response scale. Conversely, roughly one of every ten respondents $(10.6 \%)$ indicated they were extremely familiar with the hydraulic fracturing process and about half (50\%) indicated they had some familiarity (scores 5 and 6 on the response scale). The mean level of familiarity with the process of hydraulic fracturing was $4.65(S D=1.67)$.

5.1.2. Descriptive results: contributions of selected information sources to self-reported knowledge about the process of hydraulic fracturing

The 15 sources that may or may not have contributed to what respondents knew about hydraulic fracturing were ranked in descending order by the percentage contributing "some/a great deal" to self-reported knowledge (see Table 1). Newspapers were the sources of information that contributed most to respondents' knowledge of the hydraulic fracturing process, followed closely by the oil/natural gas industry and internet websites. The movies Gasland and/or Gasland 2, elected city officials, and religious leader were the sources of information that contributed least to respondents' knowledge of hydraulic fracturing.

\subsection{Bivariate and multivariate analyses}

The associations between the contributions of information sources to self-reported knowledge about hydraulic fracturing and self-reported levels of familiarity with the process of hydraulic fracturing were assessed using bivariate and multivariate correlation/regression. As noted in Table 2, four bivariate associations were positive and statistically significant. Respondents who reported that internet websites, the oil/natural gas industry, regulatory agencies, and conservation/environmental groups contributed some or a great deal to their self-reported knowledge about the process of hydraulic fracturing were more likely to indicate greater levels of familiarity with hydraulic fracturing. Respondents who reported that these same sources contributed none or very little to their knowledge indicated lesser familiarity with hydraulic fracturing.

\subsubsection{Controlling for spuriousness}

Tests for spuriousness using partial correlations were also conducted. As in previous research (Theodori, 2012, 2013), mineral rights ownership and personal/familial ties to the oil/natural gas industry were included as control factors. Mineral rights ownership ( $0=$ does not own; 1 = owns) and personal/familial ties to the oil/natural gas industry $(0=$ respondent and/or family members not employed either part-time or full-time in an occupation related to the oil/natural gas industry; $1=$ respondent and/or family members employed wither part-time or full-time in an occupation related to the oil/natural gas industry) were both dummy coded. In addition, self-reported levels of trust in each of the 15 information sources to deliver unbiased, factual information on hydraulic fracturing were included as control variables. Respondents were asked to indicate the amount of trust in each of the 15 information sources to deliver unbiased, factual information on hydraulic fracturing. Response were coded as $0=$ no trust/very little trust and $1=$ some trust/a great deal of trust. Table 3 provides descriptive statistics for the control variables used in the analyses. 
Table 3

Descriptive Statistics of the Control Variables.

\begin{tabular}{|c|c|c|c|c|c|}
\hline \multirow[t]{2}{*}{ Mineral Rights Ownership } & \multirow{2}{*}{$\begin{array}{l}\mathrm{n} \\
108\end{array}$} & \multicolumn{3}{|l|}{$\begin{array}{l}\text { Does Not Own } \\
\text { Percentage }\end{array}$} & Owns \\
\hline & & \multicolumn{3}{|l|}{23} & 77 \\
\hline \multirow{3}{*}{$\begin{array}{l}\text { Personal/Familial Ties to } \\
\text { the Oil/Natural Gas } \\
\text { Industry }\end{array}$} & $\mathrm{n}$ & \multicolumn{3}{|c|}{$\begin{array}{l}\text { Respondent and/or Family Members Not Employed Either Part- } \\
\text { time or Full Time in an Occupation Related to the Oil/Gas Industry }\end{array}$} & $\begin{array}{l}\text { Respondent and/or Family Members Employed Either Part-time } \\
\text { or Full Time in an Occupation Related to the Oil/Gas Industry }\end{array}$ \\
\hline & & \multicolumn{4}{|l|}{ Percentage } \\
\hline & 102 & 34 & & & 66 \\
\hline \multirow[t]{2}{*}{ Sources of Information ${ }^{a}$} & & & \multirow[t]{2}{*}{$\mathrm{n}$} & \multicolumn{2}{|c|}{ Trust to Deliver Unbiased, Factual Knowledge on Hydraulic Fracturing } \\
\hline & & & & $\begin{array}{l}\text { None/Very Little } \\
\text { Percentage }\end{array}$ & \\
\hline \multicolumn{3}{|c|}{ Texas A\&M AgriLife Extension } & 103 & 29 & \\
\hline \multicolumn{3}{|l|}{ Internet websites } & 102 & 35 & \\
\hline \multicolumn{3}{|l|}{ Friends in community } & 104 & 37 & \\
\hline \multicolumn{3}{|l|}{ Newspapers } & 106 & 38 & \\
\hline \multicolumn{3}{|l|}{ Oil/natural gas industry } & 107 & 43 & \\
\hline \multicolumn{3}{|l|}{ Landowner groups/coalitions } & 104 & 44 & \\
\hline \multicolumn{3}{|l|}{ Neighbors } & 105 & 45 & \\
\hline \multicolumn{3}{|l|}{ Regulatory agencies } & 105 & 48 & \\
\hline \multicolumn{3}{|l|}{ University professors } & 103 & 54 & \\
\hline \multicolumn{3}{|c|}{ Conservation/environmental groups } & 104 & 62 & \\
\hline \multicolumn{3}{|c|}{ Gasland and/or Gasland 2 (the films by Josh Fox) } & 103 & 66 & \\
\hline \multicolumn{3}{|c|}{ Elected county officials } & 105 & 71 & \\
\hline \multicolumn{3}{|l|}{ Religious leaders } & 106 & 72 & \\
\hline \multicolumn{3}{|l|}{ Social media } & 104 & 73 & \\
\hline \multicolumn{3}{|l|}{ Elected city officials } & 106 & 76 & \\
\hline
\end{tabular}

a Ranked in descending order by the percentage of "some/a great deal" of trust.

As noted in Table 2, the results indicated that holding constant the effects of mineral rights ownership, personal/familial ties to the oil/natural gas industry, and trust in the corresponding information source to deliver unbiased, factual information on hydraulic fracturing had very little effect on the size or direction of the bivariate correlation coefficients. Each of the control factors consistently failed to reach statistical significance.

\section{Concluding comments}

In short, the purpose of this paper was to add to the expanding social scientific literature on shale development and hydraulic fracturing. Two primary conclusions can be drawn from this effort. First, it appears that survey respondents in the Eagle Ford Shale region of Texas perceive themselves to be slightly more familiar with the process of hydraulic fracturing than those respondents in the Marcellus Shale region of Pennsylvania (cf. Theodori et al., 2014). Whereas $40 \%$ of respondents in the Marcellus Shale study indicated having some level of familiarity with hydraulic fracturing (scores of 5 through 7 on the 7-point familiarity scale), roughly $61 \%$ of respondents in the present study reported some level of familiarity with the process (scores of 5 through 7 on the7-point familiarity scale). Second, the results of this study indicate that self-reported levels of familiarity with the process of hydraulic fracturing are positively associated with certain sources of information. Like the findings reported by Willits et al. (2016a), the strongest contributor to respondents' self-reported familiarity with hydraulic fracturing was information from the oil/natural gas industry. Regulatory agencies, conservation/environmental groups, and internet websites were also significant contributors to respondents' familiarity of hydraulic fracturing, but the strength of these relationships was somewhat weaker.

Increased understanding of the public's self-reported familiarity/knowledge of hydraulic fracturing and the sources of information that may contribute to such familiarity/knowledge should prove beneficial to representatives of the energy industry, community leaders, governmental and regulatory agency personnel, non-governmental and environmental organization representatives, and other stakeholders. Such information may shed important insights into the contemporary anti-drilling/anti-fracking and pro-drilling/pro-fracking campaigns. These insights may also improve the efficacy of stakeholders' messaging. By directing dissemination efforts towards certain information sources, interest groups can more confidently provide the nuances needed for a thoughtful and evidence-based discourse of this controversial process. Considering the findings presented here, though, future empirical and theoretical research is warranted to provide a more comprehensive understanding of self-reported familiarity/knowledge with the process of hydraulic fracturing and the associations between the contributions of information sources to such selfreported familiarity/knowledge. Such studies might include other familiarity/knowledge measures and additional sources of information.

Lastly, despite the statistical significance of our findings, at least two limitations of these data must be considered. First, the survey was only conducted in two of the 15 core counties that comprise the Eagle Ford Shale region. Recognizing county-level variations in the intensity of the energy industry's upstream activities, we propose that future studies be designed and implemented to collect data from additional core Eagle Ford Shale counties, as well as from the non-core, neighboring counties. ${ }^{3}$ A second limitation of this study dealt with the low response rate. Although less than ideal, declining response rates are becoming increasingly commonplace in survey research (Baruch and Holtom 2008; Connelly et al., 2003; Curtin et al., 2005). Recent studies have challenged the presumption that lower response rates imply increased

\footnotetext{
${ }^{3}$ As noted by Tunstall et al. (2014), the 15 core counties of the Eagle Ford Shale include: Atascosa, Bee, DeWitt, Dimmit, Frio, Gonzales, Karnes, La Salle, Lavaca, Love Oak, Maverick, McMullen, Webb, Wilson, and Zavala. The six neighboring counties include: Bexar, Jim Wells, Nueces, San Patricio, Uvalde, and Victoria.
} 
nonresponse bias, suggesting that results from studies with lower rates of response may differ little-if at all-from those with higher rates of participation (Curtin et al., 2005; Groves, 2006; Keeter et al., 2000; Gary, 2003). ${ }^{4}$ Comparisons of selected sociodemographic characteristics between the sample and Census data indicated that the survey respondents were older and more educated than the general populations within the two counties. The sample data set also included slightly higher percentages of non-whites and males than were reflected in the Census data. Due to these limiting factors, caution should be taken when generalizing the findings of this study to the larger population of the Eagle Ford Shale region and beyond.

\section{Funding}

This project was funded by a contract from the U.S Department of Energy (DOE), through the Research Partnership to Secure Energy for America (RPSEA). The information presented in this report does not necessarily reflect the views or positions of DOE or RPSEA.

\section{References}

Anderson, Brooklynn J., Theodori, Gene L., 2009. Local leaders' perceptions of energy development in the barnett shale. South. Rural Soc. 24 (1), 113-129.

Baruch, Yehuda, Holtom, Brooks C., 2008. Survey response rate levels and trends in organizational research. Hum. Relat. 61 (8), 1139-1160.

Boudet, Hilary, Clarke, Christopher, Bugden, Dylan, Maibach, Edward, Roser-Renouf, Connie, Leiserowitz, Anthony, 2014. 'Fracking' controversy and communication: using national survey data to understand public perceptions of hydraulic fracturing. Energy Policy 65, 57-67.

Colborn, Theo, Kwiatkowski, Carol, Schultz, Kim, Bachran, Mary, 2011. Natural gas operations from a public health perspective. Hum. Ecol. Risk Assess. 17, 10391056.

Connelly, Nancy A., Brown, Tommy L., Decker, Daniel J., 2003. Factors affecting response rates to natural resource-focused mail surveys: empirical evidence of declining rates over time. Soc. Nat. Resour. 16, 541-549.

Considine, Timothy J., Watson, Robert, Blumsack, Seth, 2010. The Economic Impacts of the Pennsylvania Marcellus Shale Natural Gas Play: An Update. The Pennsylvania State University, Department of Energy and Mineral Engineering, University Park, PA Retrieved 09/15/2016. http://www.jlcny.org/site/ attachments/017_PA-Marcellus-Updated-Economic-Impacts-5-1.24.10.3.pdf.

Crowe, Jessica, Ceresola, Ryan, Silva, Tony, 2015a. The influence of value orientations, personal beliefs, and knowledge about resource extraction on local leaders' positions on shale development. Rural Soc. 80 (4), 397-430.

Crowe, Jessica, Silva, Tony, Ceresola, Ryan G., Buday, A., Leonard, C., 2015b. Differences in public perceptions and leaders' perceptions on hydraulic fracturing and shale development. Soc. Perspect. 58 (3), 441-463.

Curtin, Richard, Presser, Stanley, Singer, Eleanor, 2005. Changes in telephone survey nonresponse over the past quarter century. Public Opin. Q. 69 (1), 87-98.

Davis, Charles, Fisk, Jonathan M., 2014. Energy abundance or environmental worries? Analyzing public support for fracking in the United States. Rev. Policy Res. 31, 1-16.

Dillman, Don A.., Phelps, Glenn, Tortora, Robert, Swift, Karen, Kohrell, Julie, Berck, Jodi, Messer, Benjamin L., 2009. Response rate and measurement differences in mixed-mode surveys using mail, telephone, interactive voice response (IVR) and the internet. Soc. Sci. Res. 38, 1-18.

Dillman, Don A., Smyth, Jolene D., Christian, Melani, 2014. Internet, Phone, Mail, and Mixed-Mode Surveys: The Tailored Design Method. John Wiley \& Sons, Inc, Hoboken, NJ.

Ellis, Colter, Theodori, Gene L., Petrzelka, Peggy, Luloff, A.E., Jackson-Smith, Douglas, 2016. Unconventional risks: the experience of acute energy development in the eagle ford shale. Energy Res. Soc. Sci. 20, 91-98.

Finkel, Madelon L., Law, Adam, 2011. The rush to drill for natural gas: a public heath cautionary tale. Am. J. Public Health 101, 784-785.

Gary, Langer, 2003. About response rates. Public Perspect. 16-18.

Groves, Robert M., 2006. Nonresponse rates and nonresponse bias in household surveys. Public Opin. Q. 70 (5), 646-675.

Hudgins, Anastasia, 2013. Fracking's future in a coal mining past: subjectivity undermined. J. Cult. Agric. 35 (1), 54-59.

Jeff, Tollefson, 2012. Air sampling reveals high emissions from gas field. Nature 482 (7384), 139-140.

\footnotetext{
${ }^{4}$ A single mode of data collection (i.e., mail survey) was used in this study. The use of two or more survey modes raises the possibility of achieving higher response rates; however, higher response rates do not necessarily translate into reduced nonresponse bias (Dillman et al. 2009; Groves, 2006).
}

Keeter, Scott, Miller, Carolyn, Kohut, Andrew, Groves, Robert M., Presser, Stanley, 2000. Consequences of reducing nonresponse in a national telephone survey. Public Opin. Q. 64 (2), 125-148.

Kelsey, Timothy W., Shields, Martin, Ladlee, Lames R., Ward, Melissa, 2011. Economic Impacts of Marcellus Shale in Pennsylvania: Employment and Income in 2009. Penn State Extension, University Park, PA Retrieved 04/15/2015. http://www. marcellus.psu.edu/resources/PDFs/Economic\%20Impact\%20of\%20Marcellus\% 20.

Kinnaman, Thomas C., 2011. The economic impact of shale gas extraction: a review of existing studies. Ecol. Econ. 70, 1243-1249.

Kreuze, Amanda, Schelly, Chelsea, Norman, Emma, 2016. To frack or not to frack: perceptions of the risks and opportunities of high-volume hydraulic fracturing in the United States. Energy Res. Soc. Sci. 20, 45-54.

Ladd, Anthony E., 2013. Stakeholder perceptions of socioenvironmental impacts from unconventional natural gas development and hydraulic fracturing in the haynesville shale. J. Rural Soc. Sci. 28 (2), 56-89.

Ladwig, Pete, Kajsa, E., Dalrymple, Dominique, Scheufele, Dietram A., Corley, Elizabeth A., 2012. Perceived familiarity or factual knowledge? Comparing operationalizations of scientific understanding. Sci. Public Policy 39, 761-774.

Macey, Gregg P., Breech, Ruth, Chernaik, Mark, Cox, Caroline, Larson, Denny, Thomas, Deb, Carpenter, David O., 2014. Air concentrations of volatile compounds near oil and gas production: a community-based exploratory study. Environ. Health 13 (1), 82.

Mason, Charles F., Muehlenbachs, Lucija A., Olmstead, Sheila M., 2015. The economics of shale gas development. Ann. Rev. Res. Econ. 7, 269-289.

Olmstead, Shelia M., Muehlenbachs, Lucija A., Shih, Jhih-Shyang, Chu, Ziyan, Krupnick, Alan J., 2013. Shale gas development impacts on surface water quality in pennsylvania. Proc. Natl. Acad. Sci. 110, 4962-4967.

Osborn, Stephen G., Vengosh, Avner, Warner, Nathaniel R., Jackson, Robert B., 2011 Methane contamination of drinking water accompanying gas-well drilling and hydraulic fracturing. Proc. Natl. Acad. Sci. 108, 8172-8176.

Perry, Simona L., 2012. Addressing the societal costs of unconventional oil and gas exploration and production: a framework for evaluating short-term, future, and cumulative risks and uncertainties of hydrofracking. Environ. Pract. 14 (4), 352 365.

Qingmin, Meng, Ashby, Steve, 2014. Distance: a critical aspect for environmental impact assessment of hydraulic fracturing. Extr. Ind. Soc. 1, 124-126.

Qingmin, Meng, 2015. Spatial analysis of environment and population at risk of natural gas fracking in the state of pennsylvania, USA. Sci. Total Environ. 515516, 198-206.

Schmidt, Charles W., 2011. Blind rush? Shale gas boom proceeds amid human health questions. Environ. Health Perspect. 119 (8), a348-a353.

Shonkoff, Seth B.C., Hays, Jake, Finkel, Madelon L., 2014. Environmental public health dimensions of shale and tight gas development. Environ. Health Perspect. 122, 787-795.

Stedman, Richard C., Jacquet, Jeffrey B., Filteau, Matthew R., Willits, Fern K., Brasier Kathryn J., McLaughlin, Diane K., 2012. Marcellus shale gas development and new boomtown research: views of new York and pennsylvania residents. Environ. Pract. 14, 382-393.

Stedman, Richard C., Evensen, Darrick, O’Hara, Sarah, Humphrey, Matthew, 2016. Comparing the relationship between knowledge and support for hydraulic fracturing between residents of the United States and the United Kingdom. Energy Res. Soc. Sci. 20, 142-148.

Theodori, Gene L., 2009. Paradoxical perceptions of problems associated with unconventional natural gas development. South. Rural Sociol. 24 (3), 97-117.

Theodori, Gene L., 2013. Perception of the natural gas industry and engagement in individual civic actions. J. Rural Soc. Sci. 28 (2), 122-134.

Theodori, Gene L., Uzunian, Adrian B., 2015a. Public Perceptions of Oil and Natural Gas Development in Karnes County, Texas: A Summary Report. Center for Rura Studies, Sam Houston State University, Huntsville, TX (Retrieved 09/14/2016 http://www.shsu.edu/dotAsset/a6f08b40-5c3b-484f-91aa-7d5d96cce162.pdf).

Theodori, Gene L., Uzunian, Adrian B., 2015b. Public Perceptions of Oil and Natural Gas Development in La Salle County, Texas: A Summary Report. Center for Rural Studies, Sam Houston State University, Huntsville, TX (Retrieved 09/14/2016 http://www.shsu.edu/dotAsset/609d37a0-7944-4b9e-9cf3-fefcf987a7e2.pdf).

Theodori, Gene L., Wynveen, Brooklynn J., Fox, William E., Burnett, David B., 2009 Public perception of desalinated water from oil and gas field operations: data from texas. Soc. Nat. Resour. 22 (7), 674-685.

Theodori, Gene L., Avalos, Mona E., Burnett, David B., Veil, John A., 2011. Public perception of desalinated water from oil and gas field operations: a replication. J. Rural Social Sci. 26 (1), 92-106.

Theodori, Gene L., 2012. Public perception of the natural gas industry: data from two barnett shale counties. Energy Sources Part B 7, 275-281.

Theodori, Gene L., Willits, Fern K., Luloff, A.E., Burnett, David B., 2014. Hydraulic fracturing and the management, disposal, and reuse of frac flowback waters: views from the public in the marcellus shale. Energy Res. Social Sci. 2, 66-74.

Tunstall, Thomas, Oyakawa, Javier, Conti, Gina, Diaz-Wells, Maricela, Hernandez, Jason, Lee, Yongsun, Loeffelholz, Vincent, Ravi, Neeraj, Rodriguez, John, Teng, Feihua, Torres, Carelli, Torres, Hector, Wang, Binbin, Zhang, John, 2014. Economic Impact of the Eagle Ford Shale. (Retrieved 08/19/2016 http:// iedtexas.org/wp-content/uploads/2014/09/2014_EFS_Release_Oct.pdf).

Weigle, Jason L., 2011. Resilience, community, and perceptions of marcellus shale development in pennsylvania wilds: reframing the discussion. Sociol. Viewpoints 27, 3-14. 
Willits, Fern K., Luloff, A.E., Theodori, Gene L., 2013. Changes in residents' views of natural gas drilling in the pennsylvania marcellus shale, 2009-2012. Journal of Rural Social Sciences 28 (3), 60-75.

Willits, Fern K. GTheodori, Gene L., Luloff, A.E., 2016a. Self-reported familiarity of hydraulic fracturing and support for natural gas drilling: substantive and methodological considerations. J. Rural Soc. Sci. 31 (1), 83-101.
Willits, Fern K., Theodori, Gene L., Luloff, A.E., 2016b. Correlates of perceived safe uses of hydraulic fracturing wastewater: data from the marcellus shale. Extr. Ind. Soc. 3, 727-735.

Willow, A.J., Keefer, S., 2015. Gendering ExtrACTION: expectations and identities in women's motives for shale energy opposition. J. Rese. Gender Stud. 5 (2), $93-$ 120 